\title{
Zpráva z 26. kongresu European Association for Cardio-Thoracic Surgery (Barcelona, Španělsko)
}

Ve dnech 27.-31. ríjna 2012 jsem se s podporou České společnosti kardiovaskulární chirurgie (ČSKVCH) zúčastnil 26. kongresu European Association for Cardio-Thoracic Surgery, který se v roce 2012 konal v Barceloně. Podpora mi byla udělena ve formě cestovního grantu, který ČSKVCH uděluje mladým chirurgům do 35 let z oboru kardiochirurgie a cévní chirurgie, kteří mají aktivní účast na některém ze zahraničních odborných kongresů.

Kongres probíhal v zavedeném trendu - 27. 10. Techno College. Zde byly prezentovány technologické novinky ve fázi klinického testování - např. externí sítka k př́pravě žilních štěpů při revaskularizaci myokardu, která by měla zajistit menší mechanické namáhání žilní stěny a s tím i delší průchodnost štěpu; Elana clip pro tvorbu periferní koronární anastomózy pomocí laseru, který jsme viděli v přímém přenosu na zvířecím modelu; instrumentárium pro transapikální implantaci aortální chlopně, které je po vytažení sheathu schopné uzavřít incizi myokardu pomocí speciální pružiny, a další. 28. 10. probíhal Postgraduate Course a následně ve dnech 29.31. 10. se uskutečnil vlastní program kongresu, kde byla prezentována aktuální témata z kardiochirurgie (dospělé i dětské), hrudní a cévní chirurgie.

Na kongresu jsem přednesl přednášku na téma Postoperative complications in the elderly related to quality of life: does it really matter?, oponentem přednášky mi byl prof. Muneretto z Brescie (Itálie).

Tímto bych rád poděkoval České společnosti kardiovaskulární chirurgie za udělení cestovního grantu, s jehož pomocí jsem se kongresu mohl zúčastnit.

MUDr. Vojtěch Kurfirst, Kardiochirurgické oddělení, Nemocnice České Budějovice, a. s., e-mail: vojtech.kurfirst@post.cz 